\title{
EFEKTIVITAS LAYANAN BIMBINGAN KELOMPOK MENGGUNAKAN SOSIODRAMA DALAM MENGURANGI KECEMASAN BERKOMUNIKASI REMAJA DI NAGARI PANTI SELATAN KABUPATEN PASAMAN
}

\author{
Rezy Widya Fatma ${ }^{1}$, Alfi Rahmi ${ }^{2}$ \\ Prodi Bimbingan Konseling, FKIP, Institut Agama Islam Negeri Bukittinggi
}

\begin{abstract}
This study departs from the phenomenon of the existence of teenagers who experience communication anxiety where teenagers are nervous when communicating with new people, shaking and hesitating when expressing opinions in front of a crowd and their facial color changes when asked to talk to a crowd. The aim of this study is to determine the effectiveness of group guidance services using sociodrama in reducing communication anxiety among adolescents in the southern village of the Pasaman Regency.

This research is a pre-experimental research with One Group Pretest Posttest Design model. The population is several youths of the southern village village, while the research sample is teenagers who experience high communication anxiety based on the purposive sampling technique and the results of the pretest. The data collection instrument is a Liker scale. The data analysis technique uses the homogeneity test and the Wilcoxon test, while the data analysis requirements use the SPSS version 15 hypothesis test.

The research results that have been known from the Wilcoxon test results show differences between the pretest and posttest scores. From the calculation results of the Wilcoxon test, a significant p-value of 0.005 was obtained. Based on the applicable provisions, it is known that the Wilcoxon Sig p-value test result is $0.005<(0.05)$ which means $\mathrm{Ha}$ is accepted and Ho is rejected. From the calculation results of the Wilcoxon test, it can be concluded that there is a decrease in adolescent communication anxiety for pretest and posttest through group guidance services using sociodrama.
\end{abstract}

Keywords: Group Guidance Services Using Sociodrama, Communicating Anxiety

\section{ABSTRAK}

Penelitian ini beranjak dari fenomena terdapatnya remaja yang mengalami kecemasan berkomunikasi dimana remaja gugup ketika berkomunikasi dengan orang yang baru dikenal, gemetar dan ragu-ragu ketika menyampaikan pendapat dihadapan orang banyak serta adanya rona wajah yang berubah saat disuruh untuk berbicara dengan orang banyak. Tujuan yang akan dicapai dalam penelitian ini adalah untuk mengetahui efektifitas layanan bimbingan kelompok menggunakan sosiodrama dalam menggurangai kecemasan berkomunikasi remaja di nagari panti selatan kabupaten pasaman.

Penelitian ini adalah penelitian Pre Ekperimen model One Group Pretest Posttest Design. Populasi adalah beberapa remaja nagari panti selatan, sedangkan sampel penelitian adalah remaja yang mengalami kecemasan berkomunikasi yang tinggi berdasarkan teknik pusposive sampling dan hasil dari pretest. Instrument pengumpulan data adalah skala liker. Teknik analisis data menggunakan uji homogenitas dan uji Wilcoxon, sedangkan persyaratan analisis data menggunakan uji hipotesis SPSS versi 15.

Hasil penelitian yang telah diketahui dari hasil uji Wilcoxon menunjukkan perbedaan anatara nilai pretest dan posttest. Dari hasil perhitungan uji Wilcoxon di peroleh nilai signifikan pvalue sebesar 0,005. Berdasarkan ketentuan yang berlaku diketahui hasil uji Wilcoxon Sig p-value sebesar 0,005 < a $(0,05)$ yang artinya Ha diterima dan Ho ditolak. Dari hasil perhitungan uji Wilcoxon sapat disimpulkan bahwa terdapat penurunan kecemasan berkomunikasi remaja untuk pretest dan posttest melalui layanan bimbingan kelompok menggunakan sosiodrama. 


\section{PENDAHULUAN}

Masa remaja merupakan salah satu masa yang dilewati dalam setiap perkembangan individu. Remaja pada usia antara 15-18 tahun merupakan masa peralihan dari masa kanak-kanak yang penuh ketergantungan menuju pembentukan tangguang jawab. Dalam hal ini remaja yang berusia 15-18 tahun merupakan remaja yang masih duduk di kelas 3 SMP dan SMA. Proses dan hasil perkembangan remaja dipengaruhi oleh karakteristik dari masing-masing remaja. Sebagai seorang individu, remaja memiliki kebiasaan, kerakteristik, fisik dan psikis serta lingkungan dan latar belakang yang berbedabeda, sehingga mempengaruhi pembentukan kepribadian dan psikis nya seperti kecemasan berkomunikasi remaja dalam berinteraksi dengan orang lain atau lingkungan sekitar.

Kemampuan

dalam

berkomunikasi/berbicara pada dasarnya memang harus dikembangkan dan ditingkatkan dengan baik karena dari proses berkomuniasi/berbicara lisan ini menjadi dasar kemampuan pertama yang paling umum dipakai dalam kehidupan sehari-hari, khususnya dalam bidang pendidikan dan akan menjadi masalah besar apabila remaja tidak memiliki kemampuan dalam berkomuniasi/berbicara di depan umum. Ketidakmampuan dalam berkomuniasi di depan umum tersebut tentunya akan sangat mengganggu dan membuat remaja khususnya siswa merasa sulit untuk menjalani semua aktivitas dan kegiatannya dalam dunia pendidikan. Melihat keadaan dan kondisi yang digambarkan di atas, maka Tarigan mengemukakan bahwasannya berkomuniasi/berbicara adalah kemampuan mengucapkan bunyi-bunyi artikulasi atau katakata yang mengekspresikan, menyatakan serta menyampaikan pikiran, gagasan dan perasaan.

Kecemasan tersebut juga menjadi bagian dari adanya gangguan psikologis yang banyak dialami sebagian manusia dalam bahasa arab dikatakan bila sesuatu cemas maka ia akan bergerak pada tempatnya. Seperti yang Allah gambarkan dalam firmannya:

"Hai jiwa yang tenang, kembalilah kepada Tuhan mu dengan hati yang puas lagi diridai-nya, maka masuklah ke dalam jamaah hamba-hamba ku, masuklah ke dalam surgaku" (Q.S Al-Fajr ayat 27-30).

Dikatakan bahwasannya kecemasan pada dasarnya selalu ada di setiap kehidupan manusia terutama bila dihadapkan pada hal hal yang baru maupun adanya sebuah konflik. Kecemasan akan datang kepada siapapun, kapanpun dan dimanapun. Namun, tingkat kecemasan setiap orang berbeda, meskipun dihadapkan dengan masalah atau kondisi yang sama tetapi akan diinterpretasikan secara berbeda, hal ini disebabkan oleh adanya sifat subjektif dari kecemasan tersebut.

Menurut Horwitz berikut adalah ciri kecemasan berkomunikasi yaitu: Ketakutan sebelum dan selama aktivitas atau kegiatan berlangsung, Pembangkitan fisologis (kegelisahan yang ditimbulkan oleh meningkatnya aktivitas sistem saraf otonom), Pembangkit reaksi sebjektif pada diri individu, tidak dapat mengendalikan perasaan, ketakutan atau kecemasan dalam menyatakan sesuatu, perasaan takut dinilai orang lain.

Menurut Devito Kecemasan komunikasi dapat dipahami dalam dua perspektif, yaitu: Perspektif kognitif (cognitive). Ditinjau dari perspektif kognitif. "communication apprehension is a fear ofenanging in communication transaction". Kecemasan komunikasi adalah perasaan takut atau tingkat kegelisahan dalam transaksi komunikasi. Dalam perspektif ini seseorang cenderung umtuk membangun perasaan negatif serta memperkirakan hasil-hasil yang negatif pula dari transaksi komunikasi yang berlaku. Artinya, rasa cemas atau takut akan selalu membayangi dirinya dari transaksi komunikasi. Perspektif behavioral (Behaviorally). Ditinjau dari perspektif behavioral. "communication apprehension is a decreasein the frequency, the strengt and the 
likelihood of enanging in communication transactions". Kecemasan komunikasi adalah pengurangan frekuensi, kekuatan dan ketertarikan dalam transaksi komunuikasi. Gejala yang tampak dari perspektif ini bahwa seseorang akan menghindari situasi komunikasi apabila itu mengaruskan mereka untuk ikut ambil bagian atau berpartisipasi secara aktif dalam proses komunikasi. Pada situasi ini, sedapat mungkin mereka mengambil sedikit peran. Terdapat beberapa istilah yang digunakan dalam memahami gejala ini, seperti demam panggung (stage fright), kecemasan berbicara (speech enxiety), atau stress kerja (performance stress). Gejalagejala tersebut muncul manakala seseorang harus bekerja dibawah pengawasan orang lain.

Menurut Devito ada beberapa aspek dalam kecemasan berkomunikasi yaitu: aspek fisik, aspek perilaku, dan aspek kognitif. Kecemasan komunikasi dapat terjadi ketika seseorang berbicara didepan umum ataupun disituasi -situasi baru atau asing, sehingga seseorang akan menjadi cemas. Kecemasan berbicara di depan umum merupakan salah satu bagian dari kecemasan komunikasi. Gejala-gejala kecemasan berkomunikasi dihadapan terdiri dari gejala kognitif, gejala afektif, gejala perilaku, serta gejala fisiologis. Masing-masing gejala yang ditunjukkan ketika seseorang berada dalam kecemasan berbicara dihadapan umum tidak terjadi berdiri sendiri, namun kesemua gejala tersebut saling berpengaruh satu dengan yang lainnya.

Dari beberapa pernyataan, kecemasan komunikasi dapat diartikan sebagai ketakutan atau keakhawatiran individu dalam melakukan komunikasi yang berasal dari pemikiranpemikiran negatif sehingga memunculkan respon-respon fisiologis seperti perasaan gugup, tegang atau panik.

Tidak dikuasainya kemampuan berkomunikasi dalam kehidupan sehariharinya akan mempengaruhi proses dalam belajarnya maupun berbicara dengan orang lain, ditambah lagi dengan perilaku kecemasan yang ditimbulkannya. Untuk itu perilaku kecemasan berkomunikasi tersebut harus segera di tangani, agar remaja dapat meningkatkan kemampuan berkomunikasinya tersebut, dan alternatif yang diberikan salah satunya melalui layanan bimbingan kelompok yang ada dalam bimbingan dan konseling, dimana layanan bimbingan kelompok mengaktifkan dinamika kelompok untuk membahas berbagai hal yang berguna bagi pengembangan, pribadi dan pemecahan masalah individu yang menjadi peserta kegiatan kelompok.

Menurut Tohirin Bimbingan dan konseling merupakan proses bantuan atau pertolongan yang diberikan oleh pembimbing (konselor) kepada individu (konseli) melalui pertemuan tatap muka atau hubungan timbal balik antara keduanya, agar konseli memiliki kemampuan atau kecakapan melihat dan menemukan masalahnya serta mampu memecahkan masalahnya sendiri.

Layanan bimbingan kelompok merupakan layanan bimbingan yang diberikan dalam suasana kelompok. Bimbingan kelompok merupakan kegiatan informasi kepada sekelompok remaja untuk membantu mereka menyusun rencana dan keputusan yang tepat. Bimbingan kelompok merupakan bantuan kepada kelompok-kelompok kecil yang terdiri atas 2-10 remaja agar mampu melakukan pencegahan masalah, pemeliharaan nilai-nilai, dan pengembangan keterampilanketerampilan hidup yang dibutuhkan.

Bimbingan kelompok yaitu layanan bimbingan dan konseling yang memungkinkan sejumlah remaja secara bersama-sama melalui dinamika kelompok memeperoleh berbagai bahan dari berbagai narasumber atau membahas secara bersama-sama pokok bahasan (topik) tertentu yang berguna untuk menunjang pemahanan dan kehidupannya sehari-hari dan untuk perkembangan dirinya baik berbagai individu maupun sebagai pelajar dan untuk pertimbangan dalam pengambilan keputusan dan tindakan tertentu.

Menurut Tohirin dalam layanan bimbingan kelompok, aktivitas dan dinamika kelompok harus diwujudkan untuk membahas berbagai hal yang berguna bagi perkembangan 
atau pemecahan masalah individu (remaja) yang menjadi peserta layanan. Bimbingan kelompok dapat berupa penyampaian informasi dan aktivitas-aktivitas kelompok membahas masalah-masalah pendidikan, pekerjaan, pribadi, dan masalah sosial.

Jadi beberapa pendapat di atas, dapat dikatakan bahwa bimbingan kelompok merupakan salah satu proses pemberian bantuan kepada individu secara bersama-sama untuk mengentaskan suatu permasalahan dengan memanfaatkan dinamika kelompok dengan itu dalam bimbingan kelompok ini bisa melatih remaja untuk berkomunikasi agar tidak merasakan cemas dalam berkomunikasi lagi.

Bimbingan kelompok memiliki sifat yang beragam, mulai dari yang bersifat informatif sampai yang bersifat terapautik. Sedangkan dalam prateknya, bimbingan kelompok dapat dilalukan melalui berbagai teknik seperti diskusi, simulasi, latihan karyawisata, homeroom program psikodrama dan sosiodrama.

Teknik-teknik yang digunakan kemudian disesuaikan dengan konten, maksud dan tujuan pelaksanaan kegiatan bimbingan kelompok. Adapun teknik yang biasanya digunakan untuk mengangani permasalahan sosial adalah sosiodramai. Menurut Tohirin bahwa sosiodrama biasanya digunakan unutk menangani masalah sosial seperti kecemasan berkomunikasi.

Selain itu dapat dikatakan bahwa teknik sosiodrama digunakan untuk mencapai tujuan yang mengarah pada :Kehidupan sosial. Sehubungan dengan itu maka materi yang disampaikan melalui teknik sosiodrama bukan materi yang bersifat konsep-konsep yang harus dimengeti dan dipahami, tetapi berupa fakta, nilai dan Melalui permainan sosiodrama, remaja diajak untuk mengenali, merasakan suatu situasi tertentu sehingga mereka dapat menemukan sikap dan tindakan yang tepat seandainya menghadapi situasi yang sama. Diharapkan akhirnya mereka memiliki sikap dan keterampilan yang diperlukan dalam mengadakan penyesuaian sosial.
Berdasarkan dari hasil wawancara peneliti lakukan dengan beberapa remaja pada tanggal 25 Agustus 2020 terlibat adanya beberapa remaja di nagari panti selatan Ketakutan atau kecemasan dalam menyatakan sesuatu, menunjukkan kekhawatiran, seperti remaja yang takut berada di tengah khalayak ramai menghabiskan banyak waktu untuk khawatir mengenai hal-hal yang tidak menyenangkan, mulut merasa kering ketika berkomunikasi dihadapan orang banyak, bernafas pendek, kepala berdenyut-denyut, dan jantung berdebar ketika berkomunkasi dengan orang lain, grogi dalam berbicara dengan orang yang baru dikenalnya, cemas dan takut untuk berkomunikasi dengan orang yang dianggapnya asing, ada yang gugup dalam berkomunikasi serta adanya rona wajah yang berubah saat disuruh untuk berbicara dengan orang banyak, berkomunikasi dengan kalimat yang terbata-bata dan mengulang kalimat yang sama saat berkomunikasi dengan orang yang baru dikenal, sering gugup dan gemetaran ketika berkomunikasi dengan orang baru dikenalnya serta remaja diam saja saat diajak berkomunikasi dan masih adanya remaja yang tangannya berkeringat saat berkomunikasi dengan orang yang baru dikenal dan remaja panik ketika diajak berkomunikasi dengan orang lain dan lingkungannya.

Berdasarkan hasil wawancara peneliti dengan orang tua remaja pada tanggal 30 agusutus 2020, bahwa diperoleh data bahwa kondisi remaja pada umumnya menunjukkan ketidak stabilan, diperoleh hasil remaja TZ mengatakan bahwa ketika berkomunikasi dengan orang lain atau lingkungannya seperti terbata-bata dan mengulangi kalimat yang sama dan remaja TZ gugup ketika berkomunikasi dengan orang yang baru dikenal, remaja DF mengatakan gemetar dan ragu-ragu ketika menyampaikan pendapat dihadapan orang banyak dan remaja DF takut berada di tengah khalayak ramai menghabiskan banyak waktu untuk khawatir mengenai hal-hal yang tidak menyenangkan. Sedangkan NKN mengatakan tangannya berkeringat saat 
berkomunikasi dengan orang yang baru dikenal dan remaja NKN panik ketika diajak berkomunikasi dengan orang lain. Remaja RMP mengatakan ada persaan malu dan gelisah saat berkomunkasi dengan orang baru dikenalnya dan remaja RMP selalu bingung apa yang ingin di bicarakan ketika tampil dihadapan orang banyak. Remaja MYH mengatakan mulut merasa kering ketika berkomunikasi dihadapan orang banyak, bernafas pendek, kepala berdenyut-

denyut, dan jantung berdebar ketika berkomunkasi dengan orang lain. Hal ini disebabkan karena remaja memiliki kecemasan terhadap dirinya sehingga tidak mampu untuk berkomunikasi dengan orang banyak dan orang yang baru dikenalnya. Remaja yang memiliki berkomunikasi yang tinggi akan selalu berfikir negatif terhadap orang lain sehingga remaja tidak memilki kepercayaan diri dalam dirinya.

Proses pelaksanaan bimbingan kelompok menggunakan sosiodrama dengan mengaktifkan dimanika kelompok untuk membahas berbagai hal yang berguna bagi pengembangan, pribadi atau pemecahan masalah remaja yang menjadi peserta kegiatan kelompok. Dalam bimbingan kelompok di bahas topik-topik yang menjadi keperdulian bersama anggota kelompok, baik topik umum maupun masalah pribadi. Bimbingan kelompok menggunakan sosiodrama dilaksanakan tidak teratur karena bimbingan kelompok dapat dilaksanakan dan sasaran layanannya tergantung dengan kebutuhan pada saat ini.

Diharapkan dengan adanya bimbingan kelompok dengan teknik ini akan menjadi suatu solusi atau penyelesaian dari adanya kecemasan berkomunikasi yang dialami remaja. Berdasarkan fenomena yang telah dijelaskan sebelumnya, maka peneliti tertarik untuk melakukan penelitian tentang

\begin{tabular}{lcr} 
"Efektivitas & \multicolumn{1}{c}{ Bimbingan } & Kelompok \\
Menggunakan & Sosiodrama & dalam \\
Menggurangi & Kecemasan Berkomunikasi \\
Remaja di Nagari Panti Selatan Kabupaten \\
Pasaman"
\end{tabular}

\section{METODOLOGI PENELITIAN}

Penelitian ini adalah penelitian eksperimen, dimana penelitian yang dirancang sedemikian rupa, sehingga fenomena atau kejadian itu dapat diisolasi dari pengaruh lain dalam artian dapat menunjukkan pengaruh secara langsung satu variabel yang diteliti dan memperlihatkan hubungan sebab akibat dari variabel bebas dan terikat. Jenis penelitiannya sendiri yaitu Praeksperimen, jenis ini pada prinsipnya tidak dapat mengontrol validitas internal dan eksternal secara utuh, karena hanya satu kelompok yang diteliti satu kali atau kalau menggunakan dua kelompok itu tidak disamakan terlebih dahulu.

Berdasarkan permasalahan di atas, model penenlitian yang digunakan the one group pre test-post test design dimana jenis penelitian ekperimen the one group pre test-post test design adalah memberikan perlakuan terhadap sutu kelompok (tidak ada kelompok kontrol) dengan melihat perbedaan pre test dan post test sebagai hasil perlakuan.

Penelitian ini dilakukan di Nagari Panti Selatan Kabupaten pasaman. Alasan peneliti memilih tempat ini adalah karena nagari panti merupakan nagari yang remajanya masih banyaknya remaja yang merasa kecemasan dalam berkomunikasi. Untuk itu penulis tertarik untuk melaksnakan penelitian di nagari panti selatan kabupaten pasaman ,agar remaja dapat mengurangi kecemasan berkomunikasi dalam dirinya.

\section{HASIL PENELITIAN}

Berdasarkan hasil penelitian yang dilakukan dengan menggunakan layanan bimbingan kelompok menggunakan sosiodrama dalam mengurangai kecemasan berkomunikasi di Nagari Panti Selatan Kabupaten Pasaman, diperoleh bahwa hasil instrumen setalah pemberian layanan bimbingan kelompok menggunakan sosiodrama mengalami penurunan kecemasan berkomunikasi remaja dari pada sebalum pemberian perlakuan (treatment). Hal ini dapat dilahat daei perbedaan hasil pretest dan posttest. 
Berdasarkan pengolahan hasil pretest dan posttest kelompok eksperimen dengan jumlah sampel 10 orang remaja, nilai hasil prestest dengan meannya 142,30 yang merupakan rata-rata kecemasan berkomunikasi remaja yang tergolong pada kategori sedang, variannya adalah 423,122, standar deviasinya adalah 20,570 sedangkan tertinggi 174 dan terendah 122. Maknanya kategori kecemasan berkomunikasi remaja sebelum diberikan perlakuan (treatment) tergolong pada kategori sedang.

$$
\text { Sedangkan setelah diberikan }
$$

perlakuan (treatment) hasil pengolahan data dapat dikatahui bahwa hasil posttest dengan sampel 10 orang remaja dengan meannya 212,30, yang meruapkan rata-rata kecemasan berkomunikasi remeja yang tergolong kategori sangat rendah, variannya adalah 264,456, stadar deviasinya 16,26 sedangkan nilai tertinggi 230 dan nilai terendah 189. Maka dapat disimpulkan bahwa rata-rata skor posttest tergolong kategori sangat rendah untuk kecemasan berkomunikasi artinya terdapat penurunan kecemasan berkomunikasi pada remaja di Nagari Panti Selatan Kabupaten Pasaman.

Hasil Uji Wilcoxon menunjukkan bahwa nagative ranks atau selisih negatif antara hasil penurunan kecemasan berkomunikasi untuk pretest dan posttest adalah 0 data negatif artinya tidak terdapat penurunan kecemasan berkomunikasi remaja, mean ranks sebesar 0,00 sedangkan sum of ranks sebesar 0,00. Disini terdapat 10 data positif $(\mathrm{N})$ artinya terdapat 10 orang remaja yang mengalami penurunan kecemasan berkomunikasi dari pretest dan posttest. Mean ranks atau rata-rata penurunan kecemasannya tersebut adalah 5,50. Ties adalah kesamaan nilai pretsest dan nilai posttest, disini ties adalah 0 sehingga dapat dikatakan bahwa tidak terdapat nilai yang sama anatara prestest dan posttest. Dari penjelasan di atas dapat dikatan bahwa terdapat penurunan kecemsan berkomunkasi remaja.

Uji hipotesis pretest dan posttest, dengan dikonversikan nilai $\mathrm{Z}$ maka sebesarnya
2,807, diperoleh nilai signifikan $p$-value 0,005 berdasarkan ketentuan yang berlaku dikatahui hasil Uji wilcoxon sig $p$-value $0,005<\alpha(0,05)$ yang artinya $\mathrm{Ha}$ diterima. maka dapat disimpulkan bahwa Ha diterima Ho ditolak maka dapat dikatan terdapat penurunan kecemasan berkomunikasi remaja untuk pretest dan posttest, sehingga dapat dikatakan bahawa layanan bimbingan kelompok menggunakan sosiodrama afektif dalam menggurangai kecemasan berkomunikasi remaja di Nagari Panti Selatan Kabupaten Pasaman.

Strategi atau upaya yang dilakukan dalam mengatasi kecemasan berkomunikasi remaja di Nagari Panti Selatan yaitu dengan salah satunya melaksanakan progaram bimbingan dan konseling dalam hal ini adalah bimbingan kelompok. Menurut prayitno bimbingan kelompok yaitu layanan bimbingan dan konseling yang memungkinkan sejumlah remaja secara bersama-sama melalui dinamika kelompok memperoleh berbagai bahan dari berbagai nara sumber tertentu dan membahas secara bersama-sama pokok bahas (topik) tertentu yang berguna untuk menunjang pemahanan dan kehidupannya sehari-hari dan untuk perkembangan dirinya baik berbagai individu maupun sebagai pelajar dan untuk pertimbangan dalam pengambilan keputusan dan tindakan tertentu.

Layanan bimbingan kelompok sendiri dibantu dengan menggunakan sosiodrama dimana sosiodrama dilakukan dengan permainan peranan yang ditujuan untuk memecahkan masalah sosial seperti kecemasan berkomunikasi yang timbul dalam hubungan antar manusia dan mengajarkan cara-cara bertingkah laku dalam hubungan antara sesama manusia sehingga remaja dapat merasakan secara langsung pengalaman yang didapatkan melalui perannya.

$$
\text { Menurut Armai Arief tujuan }
$$

sosiodrama, yaitu:
a. Agar remaja dapat menghayati dan menghargai perasaan orang lain
b. Dapat belajar bagaimana bertanggung jawab 
c. Dapat belajar bagaimana mengambil keputusan dalam situasi kelompok secara spontan

d. Dapat berfikir dalam memecahkan masalah

a. Kemampuan remaja untuk memecahkan masalahnya

Melalui layanan bimbingan kelompok menggunakan sosiodrama, remaja sebagai anggota kelompok merasakan bebas menyampaikan pendapatnya, memambah wawasan, menunjang tingkah laku untuk mengendalikan diri serta dapat memecahkan masalah nya dengan bermain peran yang dilakukan dalam drama.

Jadi dapat disimpulkan bahwa layanan bimbingan kelompok menggunakan sosiodrama dapat menjadi alternatif untuk menggurangi kecamasan berkomunikasi remaja di Nagari Panti Selatan.

\section{KESIMPULAN}

Berdasarkan hasil penenlitian yang telah kemukakan, maka dapat diambil kesimpulan sebagai berikut:

1. Hasil pretest dengan jumlah sampel 10 orang remaja sebelum diberikan layanan bimbingan kelompok menggunakan sosiodrama, meannya adalah 142,30 yang mana ini adalah rata-rata kecemasan berkomunikasi sebelum diberikan perlakuan (treatment) dan rata-rata nilai ini tergolong dalam kategori sedang.

2. Hasil posttest dengan jumlah sampel 10 orang remaja setelah diberikan layanan bimbingan kelompok menggunakan sosiodrama, meannya adalah 212,30 yang mama ini adalah rata-rata kecemasan berkomunikasi setalah di berikan perlakuan (treatment) dan nilai ini tergolong dalam kategori sangat rendah.

3. Terdapat perbedaan antara nilai pretest dan posttest, pernyataan ini didukung dengan dibuktikan dari hasil asymp sig (2-tailed) diperoleh nilai sebesar 0,005 yang berarti lebih kecil dari alpha 0,05. Maka dapat dikatakan $\mathrm{Ha}$ diterima dan Ho ditolak artinya terdapat penurunan kecemasan berkomunikasi remaja untuk pretest dan posttest melalui layanan bimbingan kelompok menggunakan sosiodrama.

\section{DAFTAR KEPUSTAKAAN}

Atkinson. 2010. Pengantar Psikologi. Jakarta: Erlangga

Apriyenti. 2014. "Efektifitas restrukturisasi Kognitif untuk Mereduksi kecemasan Komunikasi pada Remaja: Penelitian Pra-Eksperimen Terhadap Peserta Didik Kelas X Pasunda 2 Bandung Tahun Ajaran 2013/2014". (Bandung: Skripsi)

Apriyenti, Seli. 2014. “Efektivitas Teknik Restrukturitas Kognitif untuk Mereduksi Kecemasan Komunikasi pada Remaja”. (Bandung: Skripsi, )

A Muri Yusuf, 2014. Metodologi Penelitian (kuantitatif, kualitatif dan penelitian gabungan), Padang: UNP Press

Burhan Bungin, 2006. Metodologi Penelitian Kuantitatif. Jakarta:Jakarta Putra Grafika

Dona Fitri Annisa and Ifdil Ifdil, 'Konsep Kecemasan (Anxiety) Pada Lanjut Usia (Lansia)', Konselor, 5.2 (2016), 93 https://doi.org/10.24036/02016526480$\underline{0-00}$

Eka Nur Septiana, Alfi Rahmi, and Rahmawati Wae, 'Efektivitas Konseling Kelompok Dengan Analisis Transaksional Untuk Mereduksi Kecemasan Berbicara Di Depan Kelas Di SMPN 8 Bukittinggi', Educational Guidance and Counseling Development Journal, 3.2 (2020), 6975 .

Hartono dan Boy Soedarmadji, 2012. Psikologi Konseling, Jakarta: Kencana Prenada Media Group

Intan Sari, Layanan Bimbingan Kelompok untuk Pencegahan Paham Radikalisme di Perguruan Tinggi Islam. Jurnal Kajian Keagamaan dan Kemasyarakatan. Vol. 03 No 02 (2019), 122 http://ejournal.iainbukittinggi.ac.id/inde x.php/fuaduna/index. 
Jonathan Sarwono, 2006. Metode Penelitian Kuantitatif dan Kualitatif, Yogyakarta: Graha Ilmu

Marabonggala Mukafih Siregar. Penerapan Metode Sosiodrama untuk Meningkatkan Kemampuan Interpersonal Siswa Kelas VII SMP Negeri 5 Depok Slamen Yogyakarta Tahun Ajaran 2014. (Yogyakarta: Skripsi)

Prayitno. 2001. Panduan Pengawasan Bimbingan dan Konseling di Sekolah. Jakarta: Rineka Cipta

Prayitno. 2012. Jenis layanan dan kegiatan pendukung konseling. Padang: FIP-UNP

Prayitno dan Erman. 2004. Dasar-dasar Bimbingan dan Konseling. Jakarta: Asdi Mahasatya

Prayitno. 2004. Seri Kegiatan pendukung Konseling. Padang: Rajawali Pres

Rahmahidayat Sari, 2018. Metodologi Penelitian. Bukittinggi: Suci Percetakan \& Photocopy,

Rayyan Rey " Teknik Sosiodrama didalam Bimbingan dan Konseling Sosial" (online) tersedia http://rayyanrey.blogspot.com.id/2019/1 2/teknik-sosiodrama.html

Ririn, Asmidir dan Marjohan, Jurnal Konselor, Volume 2 No.1. 2013. hlm. 273. Hubungan antara Keterampilan Komunikasi dengan Kecemasan Berbicara di Depan Umum, diakses pada tanggal 24 juli 2020, pukul: 11.32

Shagita, D.S, Titin. Self-Efficacy dengan Kecemasan Komunikasi pada Mahasiswa dalam Mempresentasikan Tugas didepan Kelas. Jurnal

Suharsimi Arikunto. 2013. Manajemen Penelitian. Jakarta: Rineka Cipta

Sumadi Suryabrata. 2012. Metode Penelitian. Jakarta: Raja Grafindo Persada

Sofyan. 2015. Pengaruh kecemasan berkomunikasi terhadap prestasi akademik mahasiswa. Jurnal Biotek, Vol 3 No. 2

Yeni Afrida, 2015. Efektifitas Teknik Sosiodrama untuk Mengembangkan Kertarikan Sosial Siswa: Studi Kuasi Eksperimen terhadap Siswa Gifted Kelas Unggualan di Pondok Pesantren Modern Almaarif Bukittinggi. Universitas Pendidikan Indonesia 